\title{
A NEW MECHANISTIC FRAMEWORK FOR EVALUATION OF CYCLIC BEHAVIOUR OF UNSATURATED UNBOUND GRANULAR MATERIALS
}

\author{
*Peerapong Jitsangiam ${ }^{1}$, Suphat Chummuneerat ${ }^{2}$, ${ }^{*}$ Korakod Nusit $^{3}$, Tawatchai Tanchaisawat ${ }^{1}$ and Hamid \\ Nikraz $^{4}$
}

\begin{abstract}
${ }^{1}$ Center of Excellence for Natural Disaster Management, Department of Civil Engineering, Chiang Mai University, Chiang Mai, Thailand; ${ }^{2}$ Bureau of Location and Design, Department of Highways, Bangkok, Thailand; ${ }^{3}$ Department of Civil Engineering, Naresuan University, Phitsanulok, Thailand; ${ }^{4}$ Department of Civil Engineering, Curtin University, Perth, Western Australia, Australia
\end{abstract}

*Corresponding Author, Received: 20 June 2017, Revised: 12 July 2017, Accepted: 2 Aug. 2017

\begin{abstract}
The unsaturated unbound granular materials (UUGMs) as a base course layer play a major role in the overall performance of the multi-layered flexible pavement system. In theory, the cyclic response of UUGMs (under traffic loading) depends greatly upon moisture content and matric suction, but these effects have been conventionally difficult to quantify. This paper presents a new mechanistic framework for characterising the cyclic behaviour of UUGMs with differing levels of moisture content and density, and in various in-service stress conditions in pavements without real cyclic testing on UUGMs. These parameters would typically be considered to gain a more precise pavement evaluation. In this study, a normalisation procedure was performed to incorporate matric suction into the cyclic response evaluation of UUGMs with a range of moisture contents and without actual suction measurement. A new soil suction model with three density-independent parameters was derived from a series of static triaxial compression tests based on the traditional triaxial facilities. The suction model developed can be used, with the Bishop effective stress constitutive model, to successfully evaluate the resilient response of UUGMs under the stated conditions. With the inclusion of matric suction, this new mechanical framework provides a more reliable resilient modulus prediction model.
\end{abstract}

Keywords: Unbound granular materials; Unsaturated soils; Soil suction; Resilient modulus; Pavements

\section{INTRODUCTION}

In the construction stage, unbound granular materials (UGMs), as a base course layer laid underneath the top surface of asphalt concrete in flexible pavements, are normally compacted under the energy of a modified Proctor condition. The aim is to achieve the desired density believed to provide durability in pavements. The amount of water added during compaction cannot practically elevate compacted UGMs up to the saturated condition. Pore fluid in granular pavement materials is generally a two-phase system containing both water and air (although other geotechnical engineering applications could include other gases or liquids). Water and air contents have been shown to affect granular pavement material response. However, the attempts to quantify this effect have typically been made through empirical methods [1] and more advanced works based on unsaturated soil concepts [2]-[7].

In recent years, advanced pavement design parameters of UGMs, including new pavement materials of construction and demolition (C\&D) materials, have been obtained from tests performed under a cyclic loading regime to simulate trafficlike actions onto a test sample. However, mostly, unsaturated conditions of UGMs, its actual conditions in road, have been disregarded for such tests. In Australia, for example, [8] has introduced more sophisticated material characterisation methods through the Repeated Load Triaxial Test (RLTT). Arulrajah et al [9, 10], Gabr et al [11] and Arulrajah et al [12-14] demonstrated employing the RLTT to evaluate resilient modulus and strain characteristics of C\&D materials. A new pavement analysis method [15] relies on more advanced procedures such as finite element analysis. However, it still does not include the effect of unsaturated soil phenomena, when considering the cyclic behaviour of aggregate base and sub-base materials, to determine suitable values of input parameters for pavement analysis [16].

This study aims to present a new mechanistic framework which includes the response of unsaturated unbound granular pavement materials (UUGMs) in RLTT procedures with no suction measurement. The proposed framework can be applied with an effective stress concept and a resilient response model of unsaturated soils to 
determine the cyclic response of UUGMs with a range of moisture contents under typical fieldloading conditions. The framework was verified using laboratory test data of a typical Western Australia aggregate base material, namely crushed rock base (CRB) [17].

\subsection{The Stress Concept for Unsaturated Soils}

Two main approaches are now widely accepted and used by geotechnical engineers to determine the shear strength of unsaturated soils. These are the effective stress approach [18] and the independent state variable approach [19].

The independent state variable approach is described using a mathematical equation in which the shear strength of unsaturated soils $(\tau)$ can be evaluated as follows:

$$
\tau=c^{\prime}+\left(\sigma-u_{a}\right) \tan \emptyset^{\prime}+\left(u_{a}-u_{w}\right) \tan \emptyset^{b}
$$

where $\sigma$ is the normal total stress, $u_{a}$ is the pore air pressure, $u_{w}$ is the pore water pressure, $c^{\prime}$ is the effective cohesion, $\emptyset^{\prime}$ is the effective internal friction angle, and $\emptyset^{b}$ is the internal friction angle with respect to the matric suction, $\left(u_{a}-u_{w}\right)$

In the originally proposed effective stress approach, the shear strength is evaluated on both the basic effective shear strength parameters of $c^{\prime}$ and $\emptyset$ ' and defined as:

$\sigma^{\prime}=\left(\sigma-u_{a}\right)+\chi\left(u_{a}-u_{w}\right)$

where $\sigma^{\prime}$ is the effective stress and $\chi$ is the effective stress parameter (i.e., the Bishop parameter), which has values from 0 for dry soils to 1 for fully saturated soils

The framework development in this study is presented as an effective solution to determining the stress of unsaturated soils (i.e., UUGMs) with the added consideration of soil suction. Based on the literature reviews, the independent state variable approach (see Eq. (1)) requires extensive and timeconsuming in-laboratory testing to determine all material parameters. In addition, the level of expertise required for determining $\emptyset^{\mathrm{b}}$ is not usually found in most laboratories [20].

For the original effective stress approach (see Eq. (2)), there are some stabilities for developing the framework in this study. The advantage of the effective stress approach is that the variation in the shear strength along with changes in total stress, pore water pressure, and pore air pressure relate to a single stress variable $\left(\sigma^{\prime}\right)$ which matches with a single stress history of the normal characterisation of the soil strength, unlike the independent state variable approach which requires more than one variable [20]. The main difficulty of the effective stress approach is the determination of $\chi$, as there is no generally reliable method to determine the values of $\chi$, particularly at relatively low saturation. However, this is of little consequence to the modelling of UUGMs, as these low saturation levels are unlikely to be encountered in actual pavement conditions [2]. Furthermore, it should be noted that the effective stress concept is a macroscopic concept and cannot be proven or disproven using a theoretical model expressed at a microscopic level [20]. Consequently, this study relies upon the effective stress approach (Eq. (2)) for the framework development.

\subsection{Cyclic Response of UUGMs}

The cyclic response of unbound granular materials is typically characterised through the resilient modulus, $\mathrm{M}_{\mathrm{r}}$ (see Eq. (3)), which is also a fundamental parameter in flexible pavement design [7].

$$
M_{r}=\frac{\sigma_{d}}{\varepsilon_{r}}
$$

where $M_{r}$ is the resilient modulus, $\sigma_{d}$ is the repeated deviator stress (cyclic vertical stress in excess of confining pressure), and $\varepsilon_{\mathrm{r}}$ is the resilient (recoverable) strain in a vertical direction.

The predictive resilient modulus model, known as the "Universal model" [21] and presented in Eq. (4), was adopted among the classical resilient modulus predictive modulus models [22]-[29] and has been investigated by [15]. This was done to consider the effect of both confining and shear stresses on the resilient modulus of UGMs. Austroads [15] believed that the application of the Universal model would be the most compatible with regard to Australian pavement base materials. A finite element program, namely APADS, was developed and also adopted (see Eq. (4)) to model the nonlinear behaviour of unbound granular materials [15].

$M_{r}=k_{1}\left[\frac{p}{p_{a}}\right]^{k_{2}}\left[\frac{\tau_{o c t}}{p_{a}}\right]^{k_{3}}$

where $p$ is the mean normal stress $\left(\frac{\sigma_{x}+\sigma_{y}+\sigma_{z}}{3}\right), \tau_{\text {oct }}$ is the octahedral shear stress $\left(\frac{\sqrt{2}}{3} \sigma_{d}\right.$ for standard triaxial compression loading; where $\sigma_{d}$ is the deviator stress), $p_{a}$ is the atmospheric pressure; and $k_{1}, k_{2}, k_{3}$ are the regression model (material) parameters

Resilient modulus characteristics are inherently complex and depend on different factors such as stress conditions, moisture contents, densities, the number of loading repetitions, compaction energy inputs, and soil thixotropic [30]. During the evolution of modern pavement engineering over the last few decades, several predictive models of $\mathrm{M}_{\mathrm{r}}$ 
have been developed in an attempt to incorporate the effects of the aforementioned factors into the $\mathrm{M}_{\mathrm{r}}$ estimation. To date, most modern pavement design and analysis methods have emphasised and demonstrated the importance of the effects of moisture content (i.e., one environmental factor). These effects can lead to a significant change in the resilient modulus of an unbound granular base material in which there is a fluctuation in material moisture contents resulting from the environment during the pavement's design life.

However, most resilient modulus predictive models that have been proposed only account for variations in stress conditions [15]. These models rely on an overall stress analysis (i.e., there is no consideration of the effective stress concept and no accounting for the resilient modulus response from the perspective of unsaturated soil mechanics, even though the pavement base materials are of an unsaturated condition). As for the unsaturated condition of normal pavement bases, however, it has been recognised that the variation in stress state conditions in pavement due to seasonal changes can be related to changes in matric suction, a fundamental variable of the stress state in unsaturated soils. Based on this fact, several studies have demonstrated the strong relationship between the resilient modulus and matric suction [3], [5]-[7]. Consequently, over the last few decades, resilient modulus predictive models which consider soil suction as a part of predictive parameters have been proposed [31]-[35]. However, all of them require suction parameters (e.g., matric suction) which are generally obtained from the suction measurements taken in laboratories or in the field. Due to the inherent difficulties of the suction measurement, resilient modulus predictive models with those suction parameters are not very practical and have as yet, not led to any implementation in most countries.

As mentioned previously, the matric suction $\left(u_{a}-u_{w}\right)$ should be incorporated into a more rational resilient modulus predictive model. The need is significant to modify the Universal model (Eq. (4)) so that it includes matric suction as one of the predictive variables. The effective stress approach [18], as represented in Eq. (2), was used to incorporate the matric suction into the Universal model. Consequently, the matric suction in terms of $\chi\left(u_{a}-u_{w}\right)$, or the effective suction confinement, can be considered with the resilient modulus model, in a similar manner to the equation proposed by [35], as shown in Eq. (5).

$M_{r}=k_{1}\left[\frac{p+\chi\left(u_{a}-u_{w}\right)}{p_{a}}\right]^{k_{2}}\left[\frac{\tau_{o c t}}{p_{a}}\right]^{k_{3}}$

where $p$ is the mean normal stress $\left(\frac{\sigma_{x}+\sigma_{y}+\sigma_{z}}{3}\right), \chi\left(u_{a}-u_{w}\right)$ is the effective suction confinement, $\tau_{\text {oct }}$ is the octahedral shear stress ( $\frac{\sqrt{2}}{3} \sigma_{d}$ for standard triaxial compression loading; where $\sigma_{d}$ is the deviator stress); $p_{a}$ is the atmospheric pressure, and $k_{1}, k_{2}, k_{3}$ are the regression model (material) parameters.

\subsection{Soil Water Retention Curve (SWRC) and $\chi\left(u_{a}-u_{w}\right)$ Model for UUGMs}

The soil water retention curve (SWRC) which is used extensively for the unsaturated soil property function estimation is proposed for virtually every physical process where soils become unsaturated [31], [36]-[39]. Furthermore, the SWRC is also widely used for the estimation of in-situ soil suction. To overcome the difficulty of soil suction measurement, as found in common geotechnical and pavement laboratories, the framework in this study was developed with selected SWRCs for UUGMs from the proposed empirical equations used to describe the SWRCs of soils [40]. Some of the commonly used SWRC equations, along with more recent SWRC equations developed within the geotechnical engineering discipline, have been presented in various literatures [39], [41]-[47].

Based on previous studies into SWRC-related unbound granular materials [2], [4], [48]-[50], The Genuchten equation [36] was selected for this study as the SWRC empirical equation to initially determine the matric suction of UUGMs with a given amount of moisture content. One of the most commonly used SWRC equation, The Genuchten equation can be rearranged to solve the issue of soil matric suction in terms of the gravimetric moisture content as follows:

$u_{a}-u_{w}=\frac{1}{a}\left[\left(\frac{w_{s}}{w}\right)^{\frac{1}{m}}-1\right]^{\frac{1}{n}}$

If the three fitting parameters, a, m, and $n$, for The Genuchten equation are known, along with the saturated gravimetric moisture content, $\mathrm{w}_{\mathrm{s}}$, the soil matric suction $\left(\mathrm{u}_{\mathrm{a}}-\mathrm{u}_{\mathrm{w}}\right)$ can be calculated for a given moisture content, $w$. The use of this equation is limited to the range between the air-entry value and the residual suction of a soil because of the asymptotic nature of the equation [47] and the overprediction of suction as a drying condition (i.e., the saturation approaches zero) [2]. However, The Genuchten equation is still practical with regard to the mechanical behaviour of UUGMs; it generally lies within a range of quite narrow suction values. It also can account for a small gap in the change in moisture content due to pavement field conditions. However, there has been debate about the SWRC of coarse granular materials used extensively in road construction in terms of whether the SWRC can be effectively used to describe such unsaturated coarse granular media. Among the relatively rare studies of 
the unsaturated behaviour of coarse granular materials, [4] proposed the work described in this study, and determined the SWRC for coarse granular materials (maximum particle size $90 \mathrm{~mm}$ ) having various gradations. The measurement was obtained using the relationship of the relative apparent permittivity measured through timedomain reflectometry (TDR) and volumetric moisture content, along with the concurrent matric suction, measured with a tensiometer. All test samples were compacted in a steel box of $200 \mathrm{~mm}$ wide, $500 \mathrm{~mm}$ long, and a target $200 \mathrm{~mm}$ thick. Compaction was achieved using a vibrating hammer applied to two equal layers of material (i.e., $100 \mathrm{~mm}$ thick for each layer). The transducer, TDR probe, and tensiometer were placed on top of the first $100 \mathrm{~mm}$ thick layer before continued compaction of the second layer. Based on the study of [4], a series of SWRCs was constructed from the measurements that were performed simultaneously with the TDR calibrations. Matric suction was monitored until a stable condition was reached. The moisture content was increased in steps, with each increase resulting in a reduction in matric suction. The test results were then fitted with the SWRC models of [42], and [36]. The Genuchten model showed a closer correlation to all measured values. A unified predictive equation [4] was then formulated, following the highest correlation for each parameter of The Genuchten model, with soil parameters as follows:

$$
\theta_{v}=\left(\frac{1}{1+\left[a\left(\ln P_{f}\right) \psi\right]^{n\left(D_{10}\right)}}\right)^{\left(1-\frac{1}{n\left(D_{10}\right)}\right)} \times\left[\theta_{s}-\theta_{r}\left(P_{f}\right)\right]+\theta_{r}\left(P_{f}\right)
$$

where $\theta_{v}$ is the volumetric moisture content; $a$ and $n$ are two out of the three fitting parameters of $a, m$, and $n$ for The Genuchten equation, whereas $\left(m=1-\frac{1}{n}\right), \psi=u_{a}-u_{w}$ is the matric suction, $\theta_{s}$ is the volumetric moisture content at saturation, $\theta_{r}$ is the residual volumetric moisture content, $P_{f}$ is the amount of fines for The Genuchten model, and $D_{10}$ is the nominal size for which $10 \%$ of the material is passing

To overcome the difficulty in dealing with the complexity of Eq. (7), and the unfamiliarity of the volumetric moisture content terms, a unified predictive equation of SWRC expressed in Eq. (7) was rearranged to solve the matric suction issue in terms of moisture content, as shown in Eq. (8).

$u_{a}-u_{w}=\frac{1}{a\left(\ln P_{f}\right)} \times\left[\left(\frac{w_{s}-1}{w-1}\right)^{\frac{1}{m}}-1\right]^{\frac{1}{n\left(D_{10}\right)}}$

where $w$ is the gravimetric moisture content, $w_{s}$ is the moisture content in the saturation condition, and $a, m, n, P_{f}$, and $D_{10}$ are the same definitions as in Eq. (7).

Pereira et al [51] revealed that the degree of saturation $(S)$ comprises two main parts: macropores $\left(S^{M}\right)$ and micropores $\left(S^{m}\right)$. Then, the factor $\chi$ was defined in terms of an effective degree of saturation $\left(S^{e}\right)$, as shown in Eq. (9). It was found that the saturation in micropores increased with higher fraction of plasticity clays. Dissimilar, saturation in micropores was negligibly small for granular material (e.g., $S^{m}$ was equal to 0.02 for decomposed tuff). This led to the development of applying the assumption that $\chi=S$ for granular materials.

$\chi=S^{e}=\frac{1}{2}\left(\left(\frac{S-S^{m}}{1-S^{m}}\right)+\left|\frac{S-S^{m}}{1-S^{m}}\right|\right)$

From Eq. (8), the terms of $\chi\left(u_{a}-u_{w}\right)$ can be obtained by multiplying $\chi$ by Eq. (8) and applying $\chi=S=\frac{\mathrm{w} G_{S}}{\mathrm{e}}$; where $\chi$ is the Bishop's parameter, $G_{S}$ is the soil-specific gravity, and $e$ is the void ratio at a particular density. Then Eq. (9) becomes Eq. (10).

$\chi\left(u_{a}-u_{w}\right)=\left(\frac{\mathrm{w} G_{s}}{\mathrm{e}}\right) \times \frac{1}{a\left(\ln P_{f}\right)} \times\left[\left(\frac{w_{s}-1}{w-1}\right)^{\frac{1}{m}}-1\right]^{\frac{1}{n\left(D_{10}\right)}}$

Based on Eq. (10), it can be clearly seen that $\chi\left(u_{a}-u_{w}\right)$ or the effective suction confinement, is required to determine the effective stress in an unsaturated soil (see Eq. (2)). The resilient modulus following Eq. (5) can be obtained through the inputs of the soil's physical properties (i.e., $w, w_{s}, e, G_{s}, P_{f}$, and $D_{10}$ ) and the three fitting parameters of The Genuchten model (i.e., $a, m$, and $n$ ). All these parameters are required for constructing the actual SWRC of unsaturated soils, and no requirement of the back calculation to determine $\chi$ values from complex and sophisticated laboratory tests (e.g., triaxial tests and direct shear tests with suction measurements).

The modified predictive resilient modulus model, with $\chi\left(u_{a}-u_{w}\right)$, is presented in Eq. (5). The new proposed model of $\chi\left(u_{a}-u_{w}\right)$, or the effective suction confinement, derived from the classical SWRC empirical equation of the modified van Genuchten model [4], is presented in Eq. (10). These were used as a basis to develop the mechanical framework for the resilient modulus of the unsaturated coarse granular pavement base material.

\subsection{Determination of the $\chi\left(u_{a}-u_{w}\right)$}

It can be seen from Eq. (5) that $\chi\left(u_{a}-u_{w}\right)$, the effective suction confinement, is required as a key variable to determine the resilient modulus. The 
results from a series of static triaxial compression tests can lead to the determination of the $\chi\left(u_{a}\right.$ $u_{w}$ ) value for the moisture content of a given soil. Heath et al [2] proposed a method to determine $\chi\left(u_{a}-u_{w}\right)$ from the results of a series of static triaxial tests. This method is based on the effective friction angle $\left(\phi^{\prime}\right)$ determined from the MohrCoulomb failure envelope and the corresponding values of the deviator stresses at failure $\left(q_{\max }\right)$ associated with the effective stress in an unsaturated soil concept [18]. The value of $\chi\left(u_{a}-u_{w}\right)$ at a given amount of moisture content can be determined by using Eqs. (11) and (12) as follows:

$$
\begin{aligned}
& \sin \emptyset^{\prime}=\frac{q_{\max }}{2 \sigma_{3}^{\prime}+q_{\max }} \\
& \sigma_{3}^{\prime}=\sigma_{3}+\chi\left(u_{a}-u_{w}\right)
\end{aligned}
$$

Fig.1, from [2], illustrates an example of results from static drained triaxial compression tests in terms of the Mohr-Coulomb failure envelope and the constant friction angle $(\phi)$. It can be seen from Fig. 1 that the Mohr-Coulomb failure envelopes depend upon the test sample densities (i.e., the void ratios of 0.241 and 0.179 ), and the differing moisture contents (i.e., $3 \%$ and $5 \%$ ) of the test samples that have the same density provide a constant friction angle $(\phi)$ in Mohr-Coulomb failure envelopes.

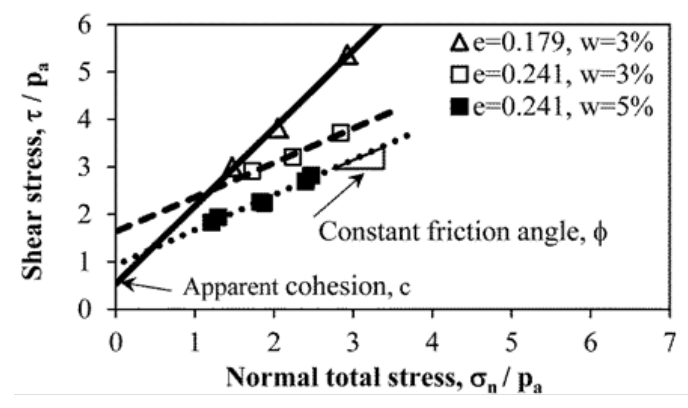

Fig.1 Mohr-Coulomb failure envelopes from drained triaxial compression tests [2].

\section{EXPERIMENTAL WORKS}

A series of triaxial compression tests and repeated load triaxial tests were performed to demonstrate and verify the proposed framework. To obtain relevant parameters for the framework, results of the repeated load triaxial tests in conjunction with those of the triaxial compression tests are required. Then, the total and effective shear strength parameters and resilient moduli of a sample material were analysed with the aforementioned relationships (i.e., Eq. (5) to Eq. (12)). Details of a material, sample preparation, and testing methods for static triaxial tests and repeated load triaxial tests are presented next.

\subsection{Materials}

Standard CRB complying with MRWA specifications [17] was sourced from a local quarry in Perth. The significant properties of CRB were examined in accordance with the MRWA specification, as shown in Table 1. The maximum particle size of CRB is $19 \mathrm{~mm}$; its particle size distribution is shown in Fig.2. The moisture-density relationship (see Fig.3) resulted from the modified compaction test, WA 133.1 [52], shows that the maximum dry density (MDD) and optimum moisture content (OMC) of CRB were $2406 \mathrm{~kg} / \mathrm{m}^{3}$ and $5.73 \%$, respectively. The moisture content at saturation of the CRB sample was $6.72 \%$.

\begin{tabular}{|c|c|c|c|}
\hline $\begin{array}{c}\text { Test } \\
\text { Methods }\end{array}$ & Tests & Specification & $\begin{array}{c}\text { CRB } \\
\text { Sample }\end{array}$ \\
\hline $\begin{array}{l}\text { WA } \\
120.2\end{array}$ & $\begin{array}{l}\text { Liquid Limit, } \\
\text { LL }\end{array}$ & $<25$ & $22.4 \%$ \\
\hline $\begin{array}{l}\text { WA } \\
121.1\end{array}$ & $\begin{array}{l}\text { Plastic Limit, } \\
\text { PL }\end{array}$ & N/A & $17.6 \%$ \\
\hline $\begin{array}{l}\text { WA } \\
122.1\end{array}$ & $\begin{array}{l}\text { Plastic Index, } \\
\text { PI }\end{array}$ & N/A & $4.8 \%$ \\
\hline $\begin{array}{l}\text { WA } \\
123.1\end{array}$ & $\begin{array}{c}\text { Linear } \\
\text { Shrinkage, LS }\end{array}$ & $0.4-2.0$ & $1.5 \%$ \\
\hline $\begin{array}{l}\text { WA } \\
216.1\end{array}$ & $\begin{array}{l}\text { Flakiness } \\
\text { Index, FI }\end{array}$ & $<30$ & $22.5 \%$ \\
\hline $\begin{array}{l}\text { WA } \\
140.1\end{array}$ & $\begin{array}{l}\text { Max. Dry } \\
\text { Compressive } \\
\text { Strength }\end{array}$ & $>1700 \mathrm{kPa}$ & $\begin{array}{l}3528 \\
\mathrm{kPa}\end{array}$ \\
\hline $\begin{array}{l}\text { WA } \\
220.1\end{array}$ & $\begin{array}{c}\text { California } \\
\text { Bearing Ratio } \\
\text { (CBR) }\end{array}$ & 80 & 180 \\
\hline
\end{tabular}

Table 1 The basic properties of CRB sample [17]

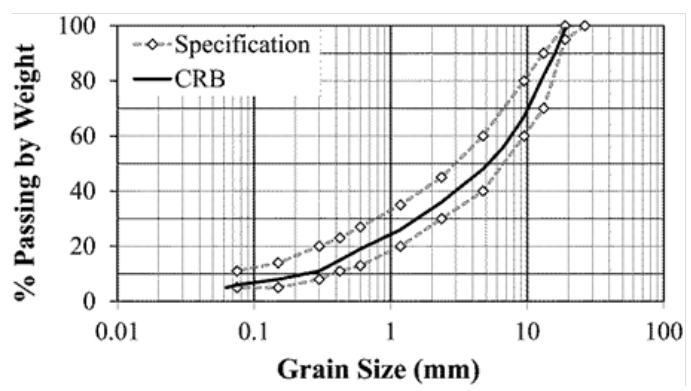

Fig.2 Particle size distribution of CRB sample 


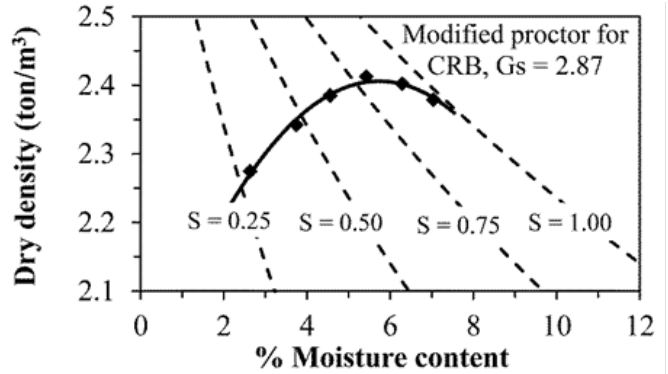

Fig.3 Compaction curve (modified proctor) of CRB with saturation curves

\subsection{Test sample preparation}

Test samples of a particular target density (i.e., 98\% MDD based on normal specifications for compaction tests for road and highway construction) were prepared with variations in the moisture content. The information from a pavement trial investigation by Main Roads Western Australia (MRWA) [53] was used to determine the range of test sample moisture contents. The results of this pavement trial showed that the moisture in a base course layer was approximately 95\% OMC at the compaction stage. Due to environmental conditions, moisture content lost over time until equilibrium was achieved was approximately 60\% OMC. Consequently, within this study, test samples were compacted at 95\% OMC to achieve a target density of $98 \% \mathrm{MDD}$, followed by two drier conditions of $80 \%$ OMC and 60\% OMC, which were set up and performed through the dryback process. In this process, the material was allowed to dry out after compaction, up to a certain amount of moisture content, with the main purpose of maximising pavement service life. The intention was also to improve the performance of asphalt surfacing by allowing satisfactory penetration of a primer binder into the pavement surface [54]. The sample preparation, with three different levels of moisture content of the same target density with regard to the dryback process, was deemed an appropriate sample preparation procedure. The goal was to avoid uncertainties during the compaction process, and to replicate the drying-out phenomena of a pavement base material in pavements, which are generally drier up to the point of equilibrium in moisture content, with one compaction at the construction stage.

Test samples for the static triaxial tests and repeated load triaxial tests were prepared similarly. All samples were compacted at target moisture content and density of 95\% OMC and 98\% MDD, respectively. Each sample was compacted in eight even layers in a mould of $100 \mathrm{~mm}$ diameter and 200 $\mathrm{mm}$ height, which is suitable for the maximum aggregate size of $19 \mathrm{~mm}$. A modified compaction applied 25 blows of a $4.9 \mathrm{~kg}$ hammer at a drop height of $450 \mathrm{~mm}$ onto each layer, which provided compaction energy of $21.62 \mathrm{~J}$ per blow. Consequently, the tests were performed at moisture contents varying from $95 \%$ down to $80 \%$ and $60 \%$ of OMC. The test samples for $80 \%$ and $60 \%$ OMC were achieved with the drying process (i.e., dryback) in a controlled chamber of $50 \%$ relative humidity at $23^{\circ} \mathrm{C}$ until the required moisture of $80 \%$ and 60\% OMC was reached.

\subsection{Consolidated-drained (CD) triaxial compression tests}

To verify the approximation that $\varnothing=\phi^{\prime}$ (detailed later in this paper), which is one of the important assumptions of the proposed framework, the effective shear strength parameters ( $c^{\prime}$ and $\left.\emptyset^{\prime}\right)$ of CRB were evaluated based on the CD triaxial tests in accordance with ASTM D7181 [55]. An advanced triaxial testing facility of the GCTS STX300 (see Fig.4) was used for this purpose. All test samples were prepared to reach the conditions of 95\% OMC and 98\% MDD. A test sample was set up in a triaxial cell without a side drain. The saturation stage was first carried out using de-aired water to fill voids in a test sample and achieve a target saturation condition. This was achieved by increasing back pressure and cell pressure in steps, incrementally. The saturation process proceeded until achieving a minimum pore pressure parameter (B) value of 0.95 . Then, the isotropic consolidation stage was conducted. The samples were subjected to shear under a drained condition. A series of tests was performed under axial compressive loading at the strain rate of $0.01 \%$ per minute. The effective confining pressures were assigned in a range of 50 , 100 , and $200 \mathrm{kPa}$.

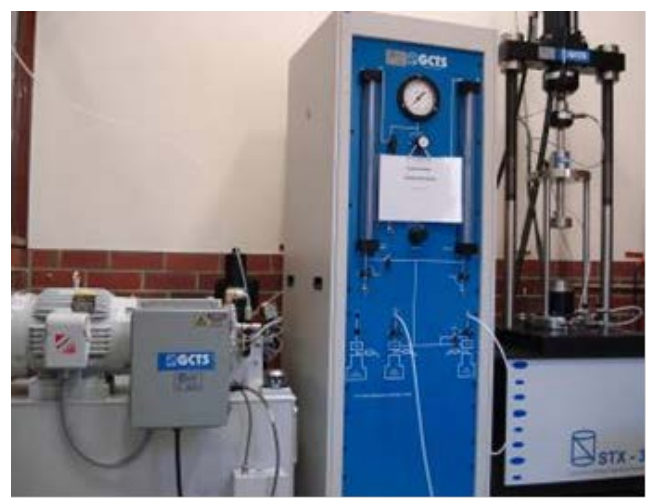

Fig.4 The GCTS STX-300 used for the CD triaxial compression tests

\subsection{Triaxial compression tests}

Static triaxial compression tests were adopted from a quick shear test after resilient and permanent deformation tests in accordance with the standard of 
AASHTO T307-99 [56] were carried out to determine the total shear strength parameters (c and $\emptyset)$ of CRB. The UTM-14P, shown in Fig.5, which is typically utilised for the repeated load triaxial tests, was used in performing this static triaxial compression test. Based on this quick shear test, following the triaxial compression test method AASHTO T307-99 [56], a certain amount of confining pressure and an applied static load with an axial strain at a rate of one percent per minute under a strain-controlled loading procedure are applied to a test sample. In this study, the representative Mohr-Coulomb failure envelope of CRB was obtained from test results of the test samples with $95 \%$ of OMC. Initially, the material responses in terms of the stress-strain curves were measured from the corresponding deviator stresses at failure in a set of three constant confining pressures at $35 \mathrm{kPa}, 70 \mathrm{kPa}$, and $100 \mathrm{kPa}$ for the CRB samples at 95\% OMC. Based on the proposed framework, while obtaining the total shear strength parameters (c and $\emptyset$ ) of CRB corresponding to its Mohr-Coulomb failure envelope, at least two more stress-strain curves of test samples which have different moisture conditions with the same density of the 95\% OMC sample are required. Therefore, in this study, further quick shear tests on CRB samples at the $80 \%$ and $60 \%$ of OMC with $35 \mathrm{kPa}$ confining pressure were carried out. A series of triaxial compression tests (quick shear tests) was performed under the assumption that the angle of internal friction is constant for samples at the same void ratio (i.e., the same dry density), even at the different moisture contents shown in Fig.1.

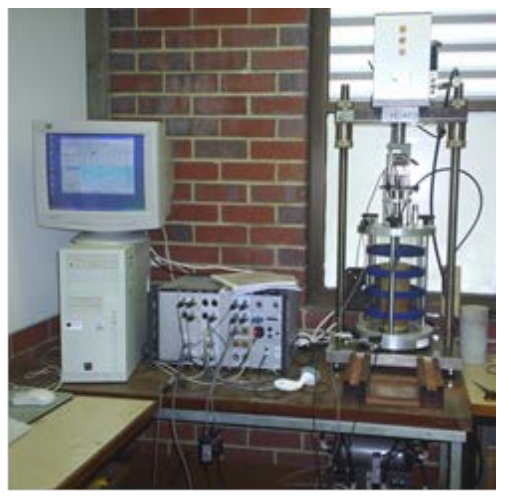

Fig.5 The UTM-14P used for static triaxial compression tests and repeated load triaxial tests

\subsection{Repeated load triaxial tests (RLTT)}

The resilient modulus was investigated through RLTT, in accordance with the test method AG: PT/T053 [8] using the UTM-14P. For the pulse loading characteristics, the dynamic vertical force was applied for a period of 3 seconds with a load pulse width of 1 second and rise and fall times of up to 0.3 seconds. The resilient modulus test was performed with 66 stress stages of different cyclic deviator stress and constant confining stress (see Fig.6) to simulate sophisticated traffic loading conditions, based on Australian experience [8], [57], [58] and other conditions [59, 60]. The stress ratio between the deviator stress and the confining stress $\left(\sigma_{d} / \sigma_{3}\right)$ varied from 2 at the first stage to 25 at the final stage. The deviator stresses varied from 100 $\mathrm{kPa}$ to $600 \mathrm{kPa}$, while the confining stresses ranged from $20 \mathrm{kPa}$ to $150 \mathrm{kPa}$. Each sample was subjected to preconditioning cycles and a minimum of fifty cycle-loadings at each stress stage. In this study, the RLTTs were performed on samples at the target dry density of $98 \%$ MDD with moisture contents varying from $95 \%$ down to $80 \%$ and $60 \%$ of the OMC.

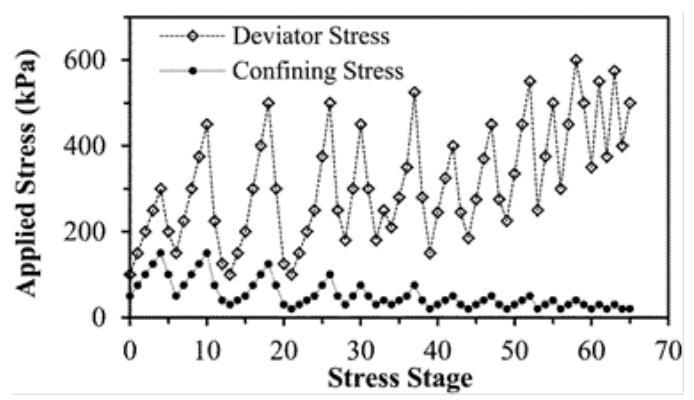

Fig.6 Applied stresses and stress stages of the resilient modulus tests [8]

\section{EXPERIMENTAL RESULTS}

\subsection{CD triaxial compression test results}

The stress-strain relationships resulting from the CD triaxial compression tests for CRB are presented in Fig.7. Then, the effective shear strength parameters can be obtained from a straight line on the basis of the Mohr-Coulomb failure criterion, as illustrated in Fig.8. Thus, the effective angle of an internal friction angle $\left(\phi^{\prime}\right)$ and a cohesion $\left(c^{\prime}\right)$ are calculated as $53.3^{\circ}$ and $95.2 \mathrm{kPa}$, respectively.

\subsection{Triaxial compression test results}

Figures 9 and 10 show the stress-strain relationships of the test samples at $60 \%, 80 \%$, and $95 \%$ of OMC and at $35 \mathrm{kPa}, 70 \mathrm{kPa}$, and $100 \mathrm{kPa}$ confining pressure levels. Mohr's circles and the Mohr-Coulomb failure envelope for these static triaxial compression tests are illustrated in Fig.11. The results show that the envelope corresponding to the peak stresses at failure is linear for the given confining pressure range (i.e., from $35 \mathrm{kPa}$ to 100 $\mathrm{kPa}$ ). Thus, the appropriate envelope corresponded to the shear strength parameters of an internal friction angle $(\phi)$ of $55^{\circ}$ and a cohesion $(c)$ of $99 \mathrm{kPa}$. 
It is assumed that the matric suction of UUGMs is relatively low in comparison with that of clayey soils. Based on the two triaxial compression test results shown in Fig.8 and Fig.11, the assumption can be made that the total friction angle $(\phi)$ is insignificantly different from the effective friction angle $(\phi)$, or approximately $\phi=\phi^{\prime}$ for the analysis of this framework. As a result, a value of $\phi=\phi^{\prime}=$ $55^{\circ}$ was applied; the corresponding values of the deviator stresses are at failure $\left(q_{\max }\right)$; and the confining pressures $\left(\sigma_{3}\right)$ of $35 \mathrm{kPa}, 70 \mathrm{kPa}$, and 100 $\mathrm{kPa}$ (see Fig.10) are substituted into Eqs. (11) and (12). Then, a set of static triaxial test results was obtained, as shown in Table 2.

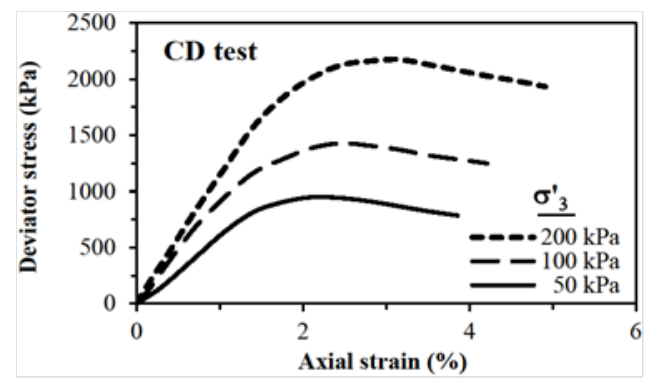

Fig.7 Stress-strain curves for CRB at a confining pressure range of $50-200 \mathrm{kPa}$ resulted from CD triaxial compression tests

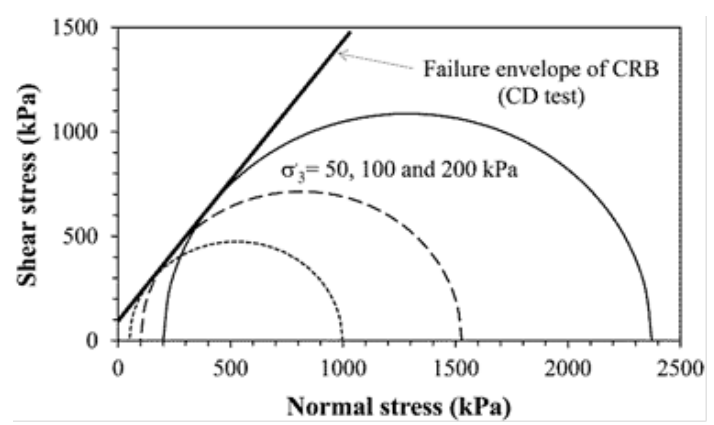

Fig.8 Mohr's circles and the Mohr-Coulomb failure envelope for $\mathrm{CRB}$ resulting from $\mathrm{CD}$ triaxial compression tests

Figure 12 shows a graph of the $\chi\left(u_{a}-u_{w}\right)$ model, demonstrating the effective suction confinement $\chi\left(u_{a}-u_{w}\right)$ across a range of moisture contents derived from Eq. (10). From this graph, the effective suction confinement, $\chi\left(u_{a}-\right.$ $u_{w}$ ), which is required for the Mr predictive model with suction (i.e., Eq. (5)), can be simply determined graphically when the moisture contents are known for CRB with various void ratios (i.e., different densities).
The three fitting parameters of The Genuchten model (e.g., $a, m$, and $n$ ) can be obtained from the regression analysis through Eq. (10) using three effective suction confinement measures $\chi\left(u_{a}-\right.$ $u_{w}$ ) from Table 2, with the CRB physical properties (e.g., $w, w_{s}, e, G_{s}, P_{f}$, and $D_{10}$ ).

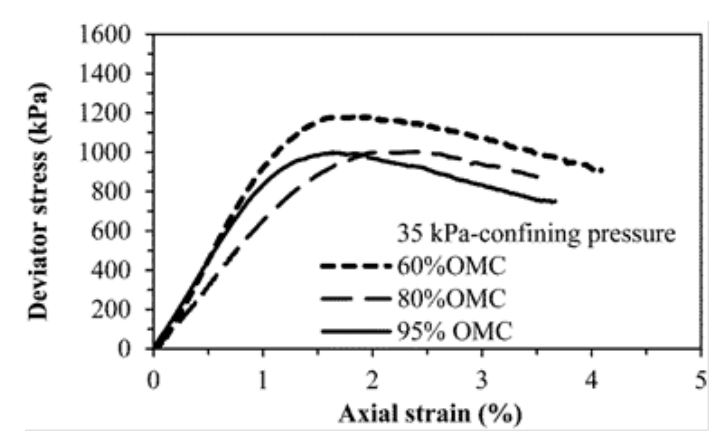

Fig.9 Stress-strain curves for CRB with moisture content varying from $60 \%$ to $95 \%$ OMC at confining pressure of $35 \mathrm{kPa}$ resulting from UU tests

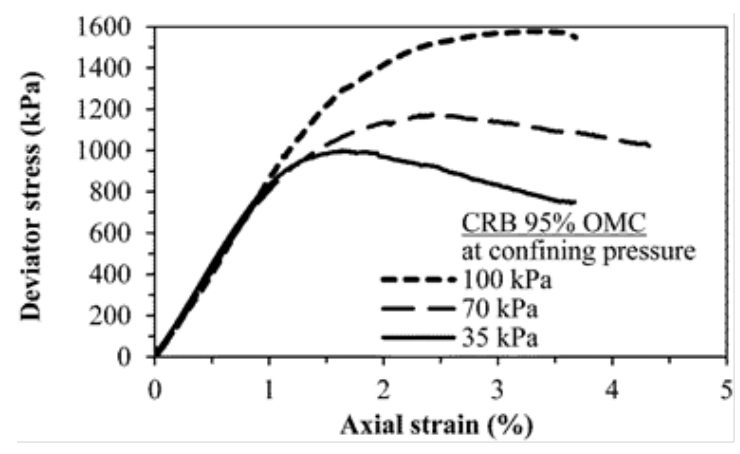

Fig.10 Stress-strain curves for CRB at 95\% OMC and confining pressure range of $35 \mathrm{kPa}$ to $100 \mathrm{kPa}$ resulting from UU tests

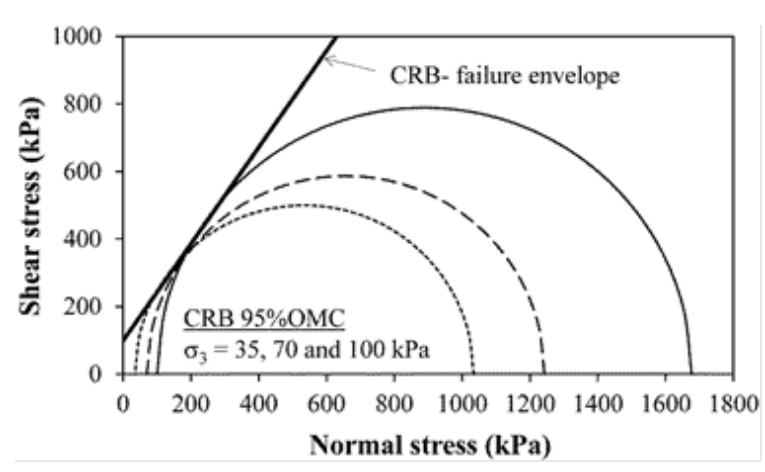

Fig.11 Mohr's circles and the Mohr-Coulomb failure envelope for CRB at 95\% OMC moisture content and 98\% MDD for determining total shear strength parameters 
Table 2 The results from static triaxial tests and analysis

\begin{tabular}{cccccccc}
\hline $\begin{array}{c}\text { Moisture } \\
\text { ratio } \\
(\% \text { OMC) }\end{array}$ & $\begin{array}{c}\text { Degree of } \\
\text { Saturation }\end{array}$ & $\sigma_{3}(\mathrm{kPa})$ & $q_{\max }(\mathrm{kPa})$ & $\phi$ & $\phi^{\prime}$ & $\sigma^{\prime}{ }_{3}(\mathrm{kPa})$ & $\begin{array}{c}\chi\left(\mathrm{u}_{\mathrm{a}}-\mathrm{u}_{\mathrm{w}}\right) \\
(\mathrm{kPa})\end{array}$ \\
\hline $95 \%$ OMC & $81.0 \%$ & 35 & 999 & 55.0 & 55.0 & 110.05 & 75 \\
$80 \%$ OMC & $68.2 \%$ & 35 & 1003 & 55.0 & 55.0 & 110.49 & 76 \\
$60 \%$ OMC & $51.2 \%$ & 35 & 1183 & 55.0 & 55.0 & 130.32 & 95 \\
\hline
\end{tabular}

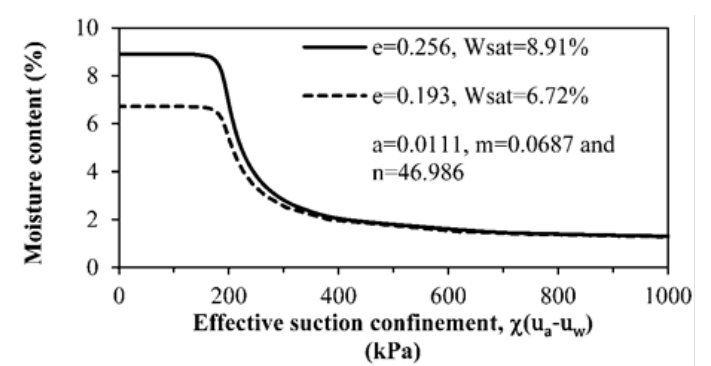

Fig.12 Effective suction confinement of CRB at different void ratios

\subsection{RLT test results}

The resilient modulus test results over 66 stress stages are presented in Fig.13. The resilient moduli of the sample at $80 \%$ OMC was slightly higher than those of the 95\% OMC sample. However, at the moisture condition of $60 \%$ OMC, the resilient moduli were significantly greater than those of the other two samples (with 80\% OMC and 95\% OMC). These results showed that an increase in resilient modulus values with a reduction of moisture content compared similarly to the peak stress of the test samples resulting from the static triaxial compression tests (Fig.9). It may be remarked that the resilient modulus value is stress and moisturedependent, but for the existing test protocol [8], the effect of moisture dependency is not considered. The proposed framework aims to remedy this shortcoming.

\subsection{Evaluation of the resilient modulus models}

The verification of the framework to estimate the resilient moduli of a pavement base material under different cyclic loading conditions in accordance with the test method AG: PT/T053 [8] can be performed by comparing the estimated values from Eqs. (4) and (5), as shown in Fig.14. For the first data set, a total stress concept was used (i.e., no consideration of soil suction), following Eq. (4). Then, the total stress regression parameters, or the material parameters (i.e., $k_{1}, k_{2}$, and $k_{3}$ ), of the model were determined using a least squares regression approach to all the test data, regardless of moisture contents, of the test sample at $80 \%$ OMC after dryback. This is usually the preference when representing the construction conditions in the field, based on Western Australian experience. For the second data set, $\chi\left(u_{a}-u_{w}\right)$ was included (see Eq. (5)) using the suction model parameters calculated from the static triaxial test data (see Table 2). In addition, a new least squares analysis was performed to obtain the effective stress model parameters of the regression analysis from all test data at $60 \%, 80 \%$, and $95 \%$ OMC, which represents moisture conditions in the field (i.e., after construction and up to an equilibrium state). Table 3 illustrates the regression (material) parameters of both $M_{r}$ predictive models with matric suction and no matric suction (i.e., Eqs. (4) and (5), respectively).

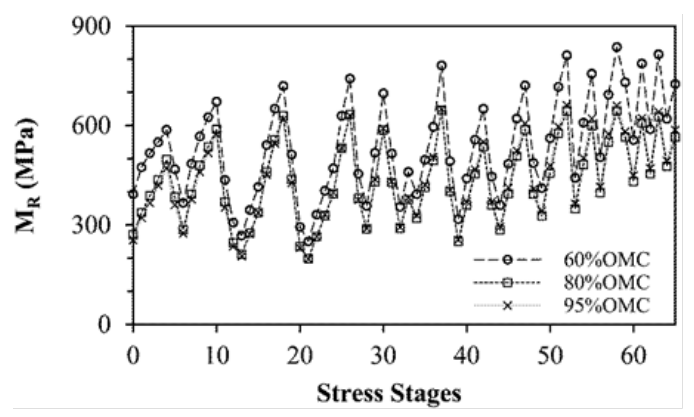

Fig.13 Resilient moduli over 66 stress stages of CRB at moisture contents $60 \%, 80 \%$ and $95 \%$ of OMC

Table 3 The regression parameters of $M_{r}$ predictive models from the validation

\begin{tabular}{cccc}
\hline \multirow{2}{*}{$\begin{array}{c}\text { Resilient modulus } \\
\text { model }\end{array}$} & \multicolumn{3}{c}{ Model regression parameters } \\
\cline { 2 - 4 } & $\mathrm{k}_{1}$ & $\mathrm{k}_{2}$ & $\mathrm{k}_{3}$ \\
& & & \\
\hline $\begin{array}{c}\text { Without matric } \\
\text { suction (80\% of } \\
\text { OMC) }\end{array}$ & 542.636 & -0.049 & 0.659 \\
$\begin{array}{c}\text { With matric suction } \\
(60 \%, 80 \% \text {, and } \\
\text { 95\% of OMC) }\end{array}$ & 244.916 & 0.602 & 0.356 \\
$\begin{array}{c}\text { Resilient modulus } \\
\text { model }\end{array}$ & 542.636 & -0.049 & 0.659 \\
\hline
\end{tabular}

It can be seen in Fig.14 that the inclusion of matric suction toward $\chi\left(u_{a}-u_{w}\right)$ produces an improved estimation of the resilient response. 
Figure 14 also shows that the predicted resilient modulus values from the total stress concept of Eq. (4) are mostly underestimated. This would not be reliable in terms of pavement design and analysis, as it would lead to an uneconomical pavement structure. It should also be noted that, based on the regression model parameters shown in Table 3, great differences exist between the regression parameter values of the $M_{r}$ predictive models from both approaches. This would raise concerns with regard to any pavement design and analysis methods which relied on the regression parameters from the $M_{r}$ predictive model, for example, regarding reliability of the total stress, in particular the Universal model [21] as represented in Eq. (4).

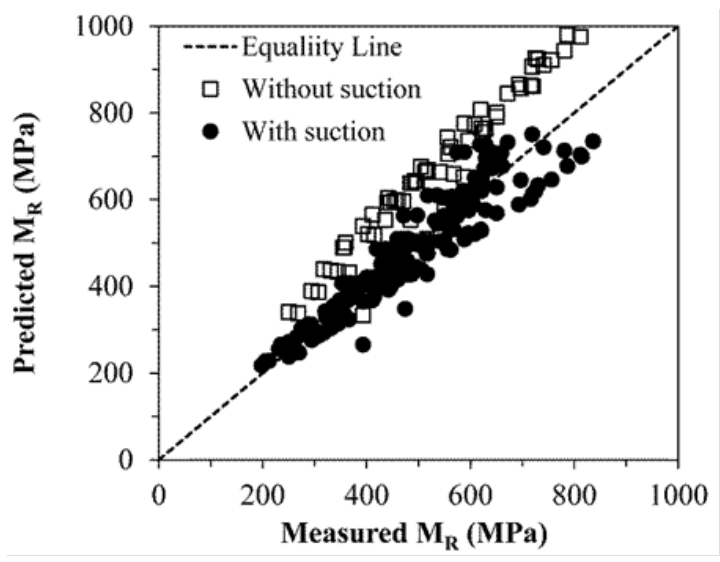

Fig.14 Comparison of measured and predicted resilient moduli

\subsection{Proposed framework}

The procedure for incorporating the unsaturated characteristics of an unbound granular base material into its cyclic behaviour in order to obtain a more reliable estimation of $M_{r}$ from the predictive model is summarised as follows:

1. Perform a series of static triaxial compression tests on at least three test samples having a given (target) density (i.e., a representative density in the field). These three tests should be performed on a range of moisture contents of which $60 \%, 80 \%, 95 \%$ OMC is suggested and prepared from the dryback process.

2. Use the Mohr-Coulomb failure criteria determined from the results of a static triaxial compression test series to obtain the total internal friction angle $(\phi)$.

3. Determine the matric suction confinement, $\chi\left(u_{a}-u_{w}\right)$ for each moisture content measure using Eqs. (11) and (12) with a corresponding confining pressure $\left(\sigma_{3}\right)$ and the deviator stress at failure $\left(q_{\max }\right)$, based on the assumption of $\phi$ $=\phi^{\prime}$. An example set of results from this step can be seen in Table 2 .
4. Perform a series of repeated load triaxial tests on at least three test samples having the same moisture content conditions as the static drained triaxial compression tests to determine the resilient moduli $\left(M_{r}\right)$ over a range of stress conditions. (In this study, the stress condition regime from [8] was used and moisture contents of $60 \%, 80 \%, 95 \%$ OMC were suggested).

5. Perform the regression analysis based on Eq. (5) and using the $M_{r}$ test results from the repeated load triaxial test series (i.e., over a moisture range of $60 \%, 80 \%$ and $95 \%$ OMC) and a set of the calculated matric suction confinement measures $\chi\left(u_{a}-u_{w}\right)$ to obtain the $M_{r}$ model parameters (i.e., $k_{1}, k_{2}$, and $k_{3}$ ).

6. The resilient modulus model with the inclusion of the matric suction confinement $\chi\left(u_{a}-u_{w}\right)$ can be finally obtained for the pavement analysis and design.

\section{CONCLUSIONS}

This paper presents a new mechanistic framework for determining the cyclic behaviour of unsaturated unbound granular materials (UUGMs), which are generally used as base course materials for flexible pavements.

The resilient modulus model with the inclusion of matric suction was also introduced, based on the procedure to obtain the matric suction confinement $\chi\left(u_{a}-u_{w}\right)$, using normalising procedures associated with an application of the effective stress concept and the principle of the SWRC equation without the actual matric suction measurement, and the regression model parameters (i.e., $k_{1}, k_{2}$, and $k_{3}$ ). There was a considerable difference between the regression parameter values of the two $M_{r}$ predictive models.

This would therefore raise concerns with regard to any pavement design and analysis methods which relied on the regression model parameters from the traditional resilient modulus predictive model, such as whether the total stress approach is still reliable or not. Thus, it can be seen that soil suction is still influential with regard to the performance of coarsegrained pavement material, and it cannot be neglected.

This is contrary to the usual practice of most geotechnical and pavement engineers who assume a low soil suction (i.e., matric suction) with regard to coarse-grained soils, and that the suction is not significant enough to affect the overall performance of unsaturated coarse-grained soils. 


\section{ACKNOWLEDGEMENTS}

The authors would like to thank the Department of Civil Engineering, Curtin University, Australia for laboratory testing contributions to this study. Moreover, the research team of the Civil Engineering Department, Chiang Mai University and Naresuan University, Thailand are also gratefully acknowledged for providing overview guidance and valuable inputs into the testing part of this work.

\section{ABBREVIATIONS AND NOTATIONS}

\begin{tabular}{|c|c|}
\hline UGMS & Unbound granular materials \\
\hline UUGMS & $\begin{array}{l}\text { Unsaturated unbound granular pavement } \\
\text { materials }\end{array}$ \\
\hline CRB & Crushed rock base \\
\hline SWRC & Soil water retention curve \\
\hline TDR & Time-domain reflectometry \\
\hline MDD & Maximum dry density \\
\hline OMC & Optimum moisture content \\
\hline MRWA & Main Roads Western Australia \\
\hline RLTT & Repeated load triaxial tests \\
\hline$w$ & Gravimetric water content \\
\hline $\boldsymbol{e}$ & Void ratio \\
\hline$G_{s}$ & Specific gravity of soils \\
\hline$\sigma$ & Normal total stress \\
\hline$u_{a}$ & Pore air pressure \\
\hline $\boldsymbol{u}_{w}$ & Pore water pressure \\
\hline$c^{\prime}$ & Effective cohesion \\
\hline$\emptyset^{\prime}$ & Effective internal friction angle \\
\hline$\emptyset^{b}$ & $\begin{array}{l}\text { Internal friction angle with Respect to the } \\
\text { matric suction }\end{array}$ \\
\hline$\sigma^{\prime}$ & Effective stress \\
\hline$\chi$ & Effective stress parameter \\
\hline $\mathrm{M}_{\mathrm{r}}$ & Resilient modulus \\
\hline$\sigma_{\mathrm{d}}$ & Repeated deviator stress \\
\hline$\varepsilon_{\mathrm{r}}$ & $\begin{array}{l}\text { Resilient (recoverable) strain in a Vertical } \\
\text { direction }\end{array}$ \\
\hline $\boldsymbol{\theta}$ & Mean normal stress \\
\hline$\tau_{\text {oct }}$ & Octahedral stress \\
\hline$p_{a}$ & Atmospheric pressure \\
\hline$k_{1}$, & Regression model (material) parameters \\
\hline$\theta_{v}$ & Volumetric water content \\
\hline$\psi$ & Matric suction \\
\hline $\boldsymbol{\theta}_{s}$ & Volumetric water content at saturation \\
\hline $\boldsymbol{\theta}_{r}$ & Residual volumetric water content \\
\hline$P_{f}$ & $\begin{array}{l}\text { Amount of fines for the van Genuchten } \\
\text { model }\end{array}$ \\
\hline$a, m, n$ & $\begin{array}{l}\text { Fitting parameters for the van Genuchten } \\
\text { equation }\end{array}$ \\
\hline$D_{10}$ & $\begin{array}{l}\text { Nominal size for which } 10 \% \text { of the material } \\
\text { is passing }\end{array}$ \\
\hline $\boldsymbol{w}$ & Gravimetric water content \\
\hline$v$ & Water content in the saturation condition \\
\hline
\end{tabular}

\section{REFERENCES}

[1] Theyse H. L., "The development of mechanisticempirical permanent deformation design models for unbound pavement materials from laboratory and accelerated pavement test data”, in Proc. 5th Int. Sym. on Unbound Aggregate in Roads, 2000, pp. 285-293.
[2] Heath A., Pestana J., Harvey J. and Bejerano M., "Normalizing Behavior of Unsaturated Granular Pavement Materials", J. of Geotechnical and Geoenvironmental Engineering, Vol. 130, No. 9, 2004, pp. 896-904.

[3] Khoury N. N., and Zaman M., "Correlation among resilient modulus, moisture variation and soil suction for subgrade soil”, Transportation Research Record, Vol. 1874, 2004, pp. 99-107.

[4] Ekblad J., and Isacsson U., “Time-domain reflectometry measurements and soil-water characteristic curves of coarse granular materials used in road pavements", Canadian Geotechnical J., Vol. 44, No. 7, 2007, pp. 858-872.

[5] Theyse H. L., Legge T. F. H., Pretorious P. C., and Wolff H., "A yield strength model for partially saturated unbound granular material”, Int. J. of Road Materials and Pavement Design, Vol. 8, No. 3, 2007, pp. 423-448.

[6] Sawangsuriya A., Edil T., and Benson C., "Effect of suction on resilient modulus of compacted finegrained subgrade soils”, Transportation Research Record, Vol. 2101, 2009, pp. 82-87.

[7] Cary C. E., and Zapata C. E., "Resilient modulus for unsaturated unbound materials", Road Materials and Pavement Design, Vol. 12, No. 3, 2011, pp. 615-638.

[8] Austroads, "Optimum use of granular bases: material selection for detailed performance evaluation”, AG: PT/T053, Austroads, Sydney, NSW, 2007.

[9] Arulrajah, A., Piratheepan, J., Ali, M. and Bo, M., "Geotechnical Properties of Recycled Concrete Aggregate in Pavement Sub-Base Applications", Geotechnical Testing Journal, Vol. 35, No. 5, 2012, pp. 743-751.

[10] Arulrajah, A., Piratheepan, J., Disfani, M. and Bo, M. W., "Resilient Moduli Response of Recycled Construction and Demolition Materials in Pavement Sub base Applications", J. of Materials in Civil Engineering, Vol. 25, No. 12, 2013, pp. 1920-1928.

[11] Gabr, A. R. and Cameron, D. A., "Properties of Recycled Concrete Aggregate for Unbound Pavement Construction", J. of Material in Civil Engineering, Vol. 24, No. 6, 2012, pp. 754-764.

[12] Arulrajah, A., Yaghoubi, E., Wong, Y. and Horpibulsuk, S., "Recycled plastic granules and demolition wastes as construction materials: Resilient moduli and strength characteristics”, Construction and Building Materials, Vol. 147, 2017, pp. 639-647.

[13] Arulrajah, A., Mohammadinia, A., Phummiphan, I., Horpibulsuk, S., and Samingthong, W., "Stabilization of recycled demolition aggregates by geopolymers comprising calcium carbide, fly ash and slag precursors”, Construction and Building Materials, Vol. 114, 2016, pp. 864-873.

[14] Arulrajah, A., Ali, M.M.Y., Disfani, M.M. and Horpibulsuk, S., "Recycled glass blends in pavement base/subbase applications: laboratory and field evaluation”, J. of Materials in Civil Engineering, Vol. 26, No. 7, 2014, pp. 04014025.

[15] Austroads, "Development of a nonlinear finite element pavement response to load model”, APT199-12, Austroads, Sydney, NSW., 2012.

[16] Austroads, "Guide to Pavement Technology Part 2: Pavement Structural Design”, AGPT02/10, Austroads, Sydney, NSW., 2010. 
[17] Main Roads Western Australia, "Specification 501 Pavements”, Main Roads Western Australia, Western Australia, 2012.

[18] Bishop A. W., "The principle of effective stress", Tecknish Ukeblad, Vol. 109, No. 39, 1959, pp. 859863.

[19] Fredlund D. G., and Rahardjo H., "Soil mechanics for unsaturated soils”, Wiley, New York, 1993.

[20] Khalili N., and Khabbaz M.H., "A unique relationship for the determination of the shear strength of unsaturated soils”, Géotechnique, Vol. 48, No. 5, 1998, pp. 681-687.

[21] Uzan J., "Resilient characterisation of granular material", Int. J. of Numerical and Analytical Methods in Geomechanics, Vol. 16, No. 6, 1992, pp. 453-459.

[22] Dunlap W. A., “A report on mathematical model describing the deformation characteristics of granular materials", Technical report no. 1, project 2-8-62-27, Transportation Institute, Texas, USA, 1963.

[23] Brown S. F., and Pell P. S., "An experimental investigation of the stresses, strains and deflections in a layered pavement structure subjected to dynamic loads", 2nd Int. Conf. on the Structural Design of Asphalt Pavements, University of Michigan, Ann Arbor, MI, USA, 1967, pp. 487-504.

[24] Monismith C. L., Seed H. B., Mitry F. G., and Chan C. K., "Prediction of pavement deflections from laboratory tests", 2nd Int. Conf. on the Structural Design of Asphalt Pavements, University of Michigan, Ann Arbor, MI, USA, 1967, pp. 109-140.

[25] Hicks R. G., "Factors influencing the resilient properties of granular materials", Ph.D. Thesis, University of California, Berkeley, CA, USA, 1970

[26] Boyce H. R., “A nonlinear model for the elastic behaviour of granular materials under repeated loading”, Int. sym. on soils under cyclic and transient loading, Swansea, Wales, A.A. Balkema, Rotterdam, the Netherlands, 1980, pp. 285-294.

[27] Johnson T. C., Berg R. L., and Dimillo A., "Frost action predictive techniques: an overview of research results”, Transportation Research Record, Vol. 1089, 1986, pp. 147-161.

[28] Nataatmadja A., and Parkin A. K., "Characterization of granular material for pavement analysis", Canadian Geotechnical J., Vol. 26, No. 4, 1989, pp. 725-730.

[29] Nataatmadja A., "Resilient modulus of granular materials under repeated loading”, 7th Int. Conf. on Asphalt Pavements, Nottingham, UK., International Society for Asphalt Pavements, Austin Texas, USA., 1992, pp. 172-185.

[30] Seed H. B., Chan C. K., and Lee C. E., "Resilience characteristics of subgrade soils and their relation to fatigue failures in asphalt pavements”, Proc. Conf. on the Structural Design of Asphalt Pavements, University of Michigan, Ann Arbor, Mich., 1962, pp. 611-636.

[31] Fredlund D. G., Began A. T., and Wong P. K., "Relation between resilient modulus and stress conditions for cohesive subgrade soils”, Transportation Research Record, Vol. 642, 1977, pp. 73-81.

[32] Parreira A. B., Goncalves R. F., "The influence of moisture content and soil suction on the Resilent modulus of a lateritic subgrade soil”, Int. Conf. on Geotechnical and Geological Engineering, Melbourne, Australia, 2000.

[33] Witczak M. W., Andrei D., and Houston W. N., "Resilient modulus as function of soil moisture summary of prediction models". Development of the 2002 Guide for the Development of New and Rehabilitated Pavement Structures, Arizona State University, Tempe, Arizona, 2000.

[34] Yang R. R., Huang W. H., and Tai Y. T., "Variation of resilient modulus with soil suction for compacted subgrade soils”, Transportation Research Record, Vol. 1913, 2005, pp. 99-106.

[35] Liang R., Rabab'ah S., and Khasawneh M., "Predicting moisture-dependent resilient modulus of cohesive soils using soil suction concept”, J. of Transportation Engineering, Vol. 134, No. 1, 2008, pp. 34-40.

[36] Genuchten M. T. V., "A closed-form equation for predicting the hydraulic conductivity of unsaturated soil”, Soil Science Society of America J., Vol. 44, 1980, pp. 892-898.

[37] Fredlund D. G., "The scope of unsaturated soil mechanics: an overview”. Invited keynote address, in: E.E. Alonso, P. Delage (Eds.) Proc. of the 1st Int. Conf. on Unsaturated Soils, Paris, France, 6-8 September 1995, A. A. Balkema, Rotterdam, the Netherlands, 1995, pp. 1155-1177.

[38] Fredlund D. G., “The 1999 R. M. Hardy Lecture: The implementation of unsaturated soil mechanics into geotechnical engineering", Canadian Geotechnical J., Vol. 37, No. 5, 2000, pp. 963-986.

[39] Fredlund D. G., and Pham H. Q., "A volume-mass constitutive model for unsaturated soils in terms of two independent stress state variables”, in: G. A. Miller, C. E. Zapata, S. L. Houston, D. G. Fredlund (Eds.) Proc. of the 4th Int. Conf. on Unsaturated Soils, ASCE, Carefree, Arizona, American Society of Civil Engineers, Reston, VA, 2006, pp. 105-134.

[40] Sillers W. S., Fredlund D. G., and Zakerzaheh N., "Mathematical attributes of some soil-water characteristic curve models", Geotechnical and Geological Engineering, Vol. 19, No. 3-4, 2001, pp. 243-283.

[41] Gardner W. R., "Some steady state solutions of the unsaturated moisture flow equation with application to evaporation from a water table”, Soil Science, Vol. 85, No. 4, 1958, pp. 228-232.

[42] Brooks R. H., and Corey A. T., "Hydraulic properties of porous media", Colorado Hydrology Paper No. 3 (March), Colorado State University, Fort Collins, 1964.

[43] Brutsaert W., "Some methods of calculating unsaturated permeability", Transactions of the ASAE (American Society of Agricultural Engineers), Vol. 10, 1966, pp. 400-404.

[44] McKee C. R., and Bumb A.C., "Flow-testing coalbed methane production wells in the presence of water and gas", Society of Petroleum Engineering (SPE) Formation Evaluation, Richardson, Tex., 1987, pp. 599-608.

[45] Fredlund D. G., and Xing A., "Equations for the soilwater characteristic curve”, Canadian Geotechnical J., Vol. 31, No. 4, 1994, pp. 521-532.

[46] Pereira J., and Fredlund D. G., "Volume change behavior of collapsible compacted gneiss soil”, J. of 
Geotechnical and Geoenvironmental Engineering, Vol. 126, No. 10, 2000, pp. 907-916.

[47] Fredlund D. G., Sheng D., and Zhao J., "Estimation of soil suction from the soil-water characteristic curve”, Canadian Geotechnical J., Vol. 48, No. 2, 2011, pp. 186-198.

[48] Fredlund D. G., "Use of the soil-water characteristic curve in the implementation of unsaturated soil mechanics”, in: J.F.T. Juca, d.C.T.M. P., F. A. M. Marinho (Eds.) Proceeding of the 3rd International Conference on Unsaturated Soils, Recife, Brazil, 10 13 March 2002, Taylor and Francis, London, 2002, pp. 887-902.

[49] Gitirana G. F. N., and Fredlund D. G., "Soil-water characteristic curve equation with independent properties", J. of Geotechnical and Geoenvironmental Engineering, Vol. 130, No. 2, 2004, pp. 209-212.

[50] Ekblad J., "Influence of Water on Coarse Granular Road Material Properties”, Ph. D. Thesis, Kungliga Tekniska Högskolan, KTH, Stockholm, 2007.

[51] Pereira J. M., and Alonso E. E., "Insight into the links between microstructure and Bishop's $\mathrm{X}$ parameter for unsaturated soils", the 4th AsiaPacific Conf. on Unsaturated Soils, Newcastle, Australia, 2009.

[52] Main Roads Western Australia, “Test Method WA 133.1 Dry Density/Moisture Content Relationship: Modified Compaction Fine and Medium Grained Soils”, Main Roads Western Australia, Western Australia, 2012.

[53] Harris D., and Lockwood N., "Pavement Engineering Report”, 2009/5 M, Main Road Western Australia, Western Australia, 2009.
[54] Australian Road Research Board, "Control of Moisture in Pavements during Construction”, APRG Technical Note 13, Australian Road Research Board, Melbourne, Australia, 2003.

[55] ASTM, "Standard test method for consolidated drained triaxial compression test for soils", D718111, ASTM International, West Conshohocken, PA, 2011.

[56] AASHTO, "Standard Method of Test for Determining the Resilient Modulus of Soils and Aggregate Materials”, T307-99, AASHTO, 2003.

[57] Jitsangiam P., and Nikraz H., "Mechanical behaviours of hydrated cement treated crushed rock base as a road base material in Western Australia”, Int. J. of Pavement Engineering, Vol. 10, No. 1, 2008, pp. 39-47.

[58] Jitsangiam P., and Nikraz H., "Coarse bauxite residue for roadway construction materials”, Int. J. of Pavement Engineering, Vol. 14, No. 3, 2012, pp. 265-273.

[59] Shehu, I. A. and Awal, A.S.M.A., Mechanical properties of concrete incorporating high volume palm oil fuel ash, Advanced Materials Research, Trans Tech Publications, Vol.599, pp.537-540, 2012.

[60] Awal, A.S.M.A., Mohammadhosseini, H. and Hossain, M.Z., Strength, modulus of elasticity and shrinkage behaviour of concrete containing waste carpet fiber, International Journal of GEOMATE, Vol.9, No.1, pp.1441-1446, 2015.

Copyright (C) Int. J. of GEOMATE. All rights reserved, including the making of copies unless permission is obtained from the copyright proprietors. 